\title{
PERBANDINGAN METODE SMART DAN MAUT UNTUK PEMILIHAN KARYAWAN PADA MERAPI ONLINE CORPORATION
}

\author{
Musri Iskandar Nasution*1, Abdul Fadlil ${ }^{2}$, Sunardi $^{3}$ \\ 1,2,3 Universitas Ahmad Dahlan, Yogyakarta \\ Email: 1'musrinst92@gmail.com, ${ }^{2}$ fadli1@mti.uad.ac.id, ${ }^{3}$ sunardi@mti.uad.ac.id \\ *Penulis Korespondensi
}

(Naskah masuk: 26 Mei 2020, diterima untuk diterbitkan: 16 November 2021)

\begin{abstract}
Abstrak
Penelitian ini merancang sistem untuk menentukan pemilihan karyawan terbaik menggunakan Sistem Pendukung Keputusan (SPK). Perhitungan sistem menggunakan metode SMART dan MAUT. SMART merupakan metode pengambilan keputusan multiatribut yang setiap alternatif terdiri dari sekumpulan atribut dan setiap atribut mempunyai nilai-nilai. Sedangkan MAUT didasarkan pada konsep dimana pembuat keputusan dapat menghitung utilitas dari setiap alternatif menggunakan fungsi MAUT dan dapat memilih alternatif dengan utilitas tertinggi. Metode SMART digunakan karena perhitungannya lebih sederhana dan memungkinkan penambahan serta pengurangan alternatif tanpa mempengaruhi perhitungan pembobotan mengingat jumlah karyawan bisa berkurang dan bertambah secara tidak teratur. Sedangkan metode MAUT digunakan karena memunculkan hasil urutan peringkat dimana akan muncul hasil nilai terbesar sampai nilai terkecil sehingga dapat diketahui karyawan dengan terbaik dengan nilai tertinggi. Sehingga dapat mengambil keputusan dengan efektif atas persoalan yang kompleks dengan menyederhanakan dan mempercepat proses pengambilan keputusan. Metode penelitian yang digunakan adalah metode pengembangan sistem model waterfall, metodologi ini terdapat tahapan-tahapan kegiatan yang harus dilakukan dalam merancang suatu sistem. Perhitungan menggunakan 30 sampel data karyawan dan empat kriteria penilaian. Empat kriteria tersebut adalah presensi dengan bobot 40, masa kerja dengan bobot 30, ijin dengan bobot 20, dan disiplin dengan bobot 10 . Data karyawan yang digunakan adalah karyawan yang sama dalam kedua metode serta mempunyai data penilaian yang sama. Hasil perhitungan menggunakan SMART dan MAUT menunjukkan bahwa keduanya dapat diimplementasikan dan berfungsi dengan baik untuk menentukan karyawan terbaik. Dengan menggunakan data alternatif, nilai alternatif, dan bobot kriteria yang sama diperoleh hasil bahwa metode SMART memberikan hasil yang lebih baik dengan 22 peringkat, sedangkan metode MAUT menghasilkan 18 peringkat. Semakin banyak jumlah peringkat yang muncul maka semakin baik karena mampu meminimalisir nilai preferensi yang sama, sehingga perankingan alternatif dapat dilakukan dengan baik.
\end{abstract}

Kata kunci: Sistem Pendukung Keputusan, SMART, MAUT, Perbandingan

\section{COMPARISON OF SMART AND MAUT METHODS FOR SELECTING EMPLOYEES ON MERAPI ONLINE CORPORATION}

\begin{abstract}
This study designed a system to determine the best employee selection using a Decision Support System (SPK). System calculations using the SMART and MAUT methods. SMART is a multi-attribute decision making method in which each alternative consists of a set of attributes and each attribute has values. Whereas MAUT is based on the concept where decision makers can calculate the utility of each alternative using the MAUT function and can choose alternatives with the highest utility. The SMART method is used because the calculation is simpler and allows the addition and subtraction of alternatives without affecting the weighting calculation given the number of employees can be reduced and increased irregularly. While the MAUT method is used because it raises the ranking order results in which the largest value will appear until the smallest value so that it can be known by the employee with the highest value. So that they can make decisions effectively on complex issues by simplifying and accelerating the decision making process. The research method used is the method of developing the system waterfall model, this methodology there are stages of activities that must be carried out in designing a system. The calculation uses 30 employee data samples and four assessment criteria. The four criteria are presence with a weight of 40, tenure with a weight of 30, permission with a weight of 20, and discipline with a weight of 10 . Employee data used are the same employees in both methods and have the same assessment data. The results of calculations using SMART and MAUT indicate that both can be implemented and function properly to determine the best employees. By using alternative data, alternative values, and the same criteria weights, the results
\end{abstract}


obtained that the SMART method gives better results with 22 ratings, while the MAUT method yields 18 ratings. The more number of ratings that appear, the better because it is able to minimize the same preference value, so that alternative ranking can be done well.

Keywords: Decision Support System, SMART, MAUT, Comparison

\section{PENDAHULUAN}

Karyawan menjadi aset penting bagi perusahaan untuk mempertahankan kelangsungan hidup dan berkembang, maupun untuk persaingan dengan perusahaan lain serta dalam mendapatkan keuntungan. Persaingan di dunia bisnis yang semakin kompetitif membuat perusahaan selalu berusaha keras dalam meningkatkan kualitas perusahaan. Salah satu yang menjadi usahanya adalah dengan meningkatkan kualitas sumber daya manusia, karena kualitas yang baik dapat meningkatkan produktivitas dan prestasi perusahaan (Rafiqi, Riyansyah and Sartika, 2018).

Merapi Online Corporation merupakan perusahaan di Yogyakarta yang bergerak di bidang jasa pelayanan akses internet. Sebagai upaya untuk memberikan semangat kepada setiap karyawan agar kinerjanya semakin meningkat, perusahaan secara rutin memberikan apresiasi kepada karyawan dengan melakukan pemilihan karyawan terbaik. Pemilihan karyawan terbaik dilaksanakan oleh tim yang sudah ditunjuk oleh perusahaan. Pemilihan karyawan terbaik yang dilakukan secara manual yang didasarkan pada kriteria yang telah ditentukan perusahaan. Kriteria tersebut meliputi data presensi, masa kerja, ijin, dan disiplin. Banyaknya karyawan dengan beberapa kriteria penilaian membuat penilaian terhadap karyawan tidak mudah dan kurang tepat.

Sistem Pendukung Keputusan (SPK) merupakan salah satu bagian dari sistem informasi yang digunakan oleh perusahaan atau organisasi yang untuk mengolah data menjadi informasi sebagai acuan dalam mengambil keputusan semi terstruktur maupun tidak terstruktur yang spesifik (Fitriani, 2019).

Perhitungan dalam SPK dapat menggunakan beberapa metode untuk pembuatan model antara lain Analytic Hierarchy Process (AHP), Technique for Order Preference by Similarity to Ideal Solution (TOPSIS), Simple Additive Weighting (SAW), Fuzzy Multiple Attribute Decision Making (FMADM), Nä̈ve Bayes, Weighted Product (WP), Simple Multi Attribute Rating (SMART), Profile Matching, Multi Attribute Ultility Theory (MAUT) dan lain sebagainya.

SMART merupakan metode yang dapat digunakan dalam sistem pengambilan keputusan multi atribut. Pilihan alternatif yang begitu banyak dapat diperhitungkan dengan teknik pengambilan keputusan multi atribut ini. Alternatif yang terpilih harus mempunyai kesesuaian dengan tujuan yang sudah ditentukan. Masing-masing alternatif terdiri dari beberapa atribut yang masing-masing atribut juga mempunyai nilai. Perhitungan nilai dilakukan dengan dihitung rata-rata menggunakan skala tertentu. Atribut mempunyai bobot yang berbeda yang menggambarkan kepentingan dari atribut tersebut dibandingkan dengan atribut yang lain. Pemberian bobot dan peringkat digunakan untuk memberi nilai masing-masing alternatif supaya didapatkan alternatif terbaik (Setiawan, Pranoto and Huda, 2020).

MAUT merupakan suatu skema evaluasi akhir, $\mathrm{v}$ (x) dari suatu objek $\mathrm{x}$ didefinisikan sebagai bobot yang dijumlahkan dengan suatu nilai yang relevan terhadap nilai dimensinya, istilah yang biasa untuk menyebutnya adalah nilai utilitas. MAUT digunakan untuk merubah dari beberapa kepentingan ke dalam nilai numerik dengan skala 0 sampai dengan 1 dengan 0 mewakili pilihan terburuk dan 1 sebagai pilihan terbaik. Hal ini memungkinkan perbandingan langsung yang beragam ukuran. Hasil akhirnya adalah urutan peringkat dari evaluasi yang menggambarkan pilihan dari para pembuat keputusan (Siringoringo and Purba, 2019).

Beberapa penelitian mengenai sistem pendukung keputusan menggunakan metode SMART atau metode MAUT antara lain mengenai metode AHP dan SMART digunakan untuk pengambilan keputusan pemberian insentif berdasarkan penilaian kinerja pada Dosen Universitas Pembangunan Panca Budi Medan. Pada tahap analisis dengan menggunakan kedua metode tersebut didapatkan hasil bahwa penilaian keputusan pemberian insentif lebih tepat menggunakan metode SMART dibandingkan menggunakan metode AHP (Wadly and Prihandoko, 2019).

Perbandingan Metode SMART dan SAW digunakan dalam SPK untuk menentukan karyawan tetap berbasis web pada PT GS Electech Indonesia. Perbandingan metode SMART dan SAW terletak pada proses perhitungannya, dimana pada metode SAW membutuhkan matrix normalisasi sedangkan pada metode SMART tidak ada (Priatna, Mulyana and Dedih, 2016).

Penerapan metode AHP dan SMART untuk pemilihan supplier terbaik pada CV. Hizkia Tirta Gemilang menghasilkan bahwa nilai terbesar diperoleh CV. Bina Karya Mandiri sebagai alternatif terbaik dalam pemilihan supplier dengan nilai akhir 0,9792 (Lestari and Mahdiana, 2019).

Metode SAW dan SMART dikomparasikan dalam SPK penentuan penerima Kartu Indonesia Pintar (KIP). Hasil penelitian menunjukkan bahwa metode SMART lebih baik dibandingkan dengan 
metode SAW untuk diimplementasikan pada SPK dalam membantu pihak sekolah dalam melakukan proses seleksi dalam menentukan penerima KIP (Veradilla Amalia, Yanto and Hamidani, 2020).

Penelitian selanjutnya membandingkan hasil perhitungan antara metode SAW dengan metode MAUT. Studi kasus ini merupakan penentuan karyawan berprestasi menggunakan data pada PT. Pertamina RU II Dumai. Metode MAUT digunakan untuk melakukan perankingan sebagai pembanding pada penelitan sebelumnya yang menggunakan Metode SAW. Dari hasil perhitungan didapatkan bawah 5 alternatif dengan nilai terbesar memiliki kemiripan dengan Metode SAW, sehingga Metode MAUT dapat dijadikan sebagai metode alternatif untuk melakukan perhitungan penentuan karyawan berprestasi (Israwan, Mukmin and Ardiansyah, 2018).

Perbandingan WP, WSM dan MAUT juga digunakan dalam sistem pendukung keputusan penerimaan tenaga kerja. Hasil yang didapatkan ditinjau dari segi akurasi, metode MAUT lebih unggul dibandingkan metode WP dan WSM (Fajarwati, Fitriasari and Siregar, 2018).

Metode MAUT juga diimplementasikan dalam pembuatan SPK untuk penerimaan karyawan PT. Dos Ni Roha Jambi. Perancangan sistem yang digunakan adalah Use case Diagram, Activity Diagram, Class Diagram dan aplikasi Adobe Dreamweaver CS6. SPK yang dibangun menghasilkan karyawan yang direkomendasikan sebanyak 4 (empat) orang dari 9 (sembilan) orang yaitu dengan nilai 14.75, 14.25, 12.26 dan 10.49 (Hidayat, Jusia and Amroni, 2018).

SPK dalam menentukan pemberian pinjaman modal dengan menggunakan metode MAUT berbasis desktop yang dibangun dapat membantu dalam menentukan calon penerima pinjaman modal usaha. Metode MAUT digunakan karena dapat menentukan prioritas dengan banyak kriteria dan dapat digunakan untuk menentukan pemberian pinjaman modal (Nasyuha, 2019).

SPK pemilihan tenaga kesehatan teladan menggunakan metode MAUT SPK mampu memberikan rekomendasi pemilihan tenaga kesehatan teladan. Hasil akurasi pada implementasi metode MAUT ini sebesar $86,67 \%$, berdasarkan dari hasil yang diperoleh menunjukkan bahwa metode dapat dijadikan metode alternatif untuk SPK pemilihan tenaga kesehatan teladan (Ramadiani and Rahmah, 2019).

Berdasarkan permasalahan yang sudah disampaikan sebelumnya dan sesuai dengan kajian penelitian terdahulu maka penelitian ini membangun membangun SPK yang menerapkan perbandingan metode perangkingan dalam menentukan karyawan terbaik menggunakan metode SMART dan MAUT. Parameter analisis yang digunakan adalah hasil perangkingan dari perhitungan kedua metode untuk menentukan metode rekomendasi.

\section{METODE PENELITIAN}

Objek penelitian yang digunakan pada penelitian ini adalah SPK untuk pemilihan karyawan terbaik. Pengambilan sampel penelitian ini dilakukan di Merapi Online Corporation Yogyakarta yang membutuhkan sistem untuk menilai kinerja karyawannya.

Teknik yang digunakan untuk mengumpulkan data adalah observasi dengan cara melakukan pengamatan langsung di lapangan penelitian yaitu Merapi Online Corporation. Wawancara dilaksanakan secara langsung kepada Manager Merapi Online Corporation Yogyakarta terkait kebutuhan kriteria dan pengujian yang digunakan dalam metode SMART dan MAUT. Studi pustaka dilakukan dengan mengumpulkan, membaca serta mempelajari data yang berasal dari berbagai media seperti buku, jurnal, karya tulis atau artikel yang terkait dengan penelitian.

Metode SMART dan MAUT membutuhkan kriteria untuk perhitungannya. Kriteria-kriteria tersebut kemudian menjadi dasar penentuan bobot alternatif untuk dibuat sebuah matriks keputusan. Kriteria-kriteria yang digunakan sebagai dasar penentuan bobot alternatif adalah sebagai berikut:

C1: Presensi, merupakan keterangan yang berisi persentase absensi karyawan selama satu bulan.

C2: Masa kerja, merupakan keterangan yang berisi jangka waktu atau lamanya seorang karyawan bekerja di perusahaan.

C3: Ijin, merupakan keterangan yang berisi jumlah hari ijin seorang karyawan selama satu bulan.

C4: Disiplin, merupakan keterangan yang berisi jumlah pelanggaran yang dilakukan oleh karyawan selama satu bulan.

Proses pengumpulan data yang dilakukan di lokasi penelitian mendapatkan hasil berupa data karyawan dan kriteria yang digunakan sebagai alat penilaian karyawan. Pembobotan dari setiap kriteria dilakukan sebelum proses implementasi data karyawan tersebut. Pembobotan ini dilakukan untuk mengetahui ukuran penilaian dari suatu kriteria. Perhitungan dengan SMART dan MAUT ini menggunakan 30 sampel data karyawan dari 55 total karyawan dan empat kriteria penilaian.

Data yang diperoleh berasal dari bagian personalia pada Merapi Online Corporation dengan melihat semua data karyawan. Data karyawan yang diperoleh berupa biografi karyawan serta data pendukung seperti presensi dan pendukung lainnya. Data yang didapat dijadikan dasar pembuatan kriteria-kriteria pendukung untuk memilih karyawan terbaik. Proses selanjutnya adalah menentukan bobot dari masing-masing kriteria dan dari masing-masing kriteria tersebut dibuat rating kecocokan kemudian 
dibuat matriks keputusan ternormalisasi sehingga diperoleh nilai dengan bobot terbesar.

Langkah-langkah perhitungan menggunakan metode SMART terdiri dari beberapa tahap yaitu:

1. Menentukan Kriteria yang digunakan dalam menyelesaikan masalah pengambilan keputusan.

2. Menentukan Bobot Kriteria

3. Normalisasi Bobot Kriteria dengan dengan membandingkan nilai bobot kriteria dengan jumlah bobot kriteria

4. Memberikan Nilai Parameter untuk Tiap Kriteria

5. Menentukan Nilai Utility dengan mengkonversikan nilai kriteria pada masingmasing kriteria menjadi nilai kriteria data baku.

6. Menentukan Nilai Akhir dengan mengalikan nilai yang didapat dari normalisasi nilai kriteria data baku dengan nilai normalisasi bobot kriteria

7. Perangkingan (Manalu, 2018)

Sedangkan untuk langkah-langkah perhitungan menggunakan metode MAUT terdiri dari beberapa langkah yaitu:

1. Mendefenisikan terlebih dahulu kriteriakriteria yang akan dijadikan tolak ukur penyelesaian masalah dan menentukan tingkat kepentingan dari setiap kriteria. 2. Menghitung nilai matriks perbandingan dari masing-masing kriteria berdasarkan tabel nilai kepentingan. 3. Menghitung nilai bobot kriteria (Wj) 4. menghitung nilai bobot preferensi (Vi) 5. Perangkingan.

1. Mendefenisikan kriteria-kriteria yang akan dijadikan pedoman dalam penyelesaian masalah.

2. Menentukan bobot relatif pada masing-masing kriteria.

3. Mendaftar semua alternatif.

4. Menghitung nilai Utility normalisasi matriks untuk masing - masing alternatif sesuai atributnya.

5. Mengalikan utility dengan bobot untuk menemukan nilai akhir masing-masing alternatif (Hadinata, 2018).

Persamaan antara metode SMART dan MAUT terletak pada konsepnya yang sama-sama digunakan dalam sistem pengambilan keputusan dengan multi atribut. Sedangkan perbedaan terletak pada metode SMART ketika ada penambahan atau pengurangan alternatif tidak akan mempengaruhi perhitungan pembobotan karena setiap penilaian alternatif tidak saling bergantung, sedangkan pada metode MAUT ketika ada penambahan maupun pengurangan alternatif maka akan berpengaruh pada proses perhitungan selanjutnya.

\section{HASIL DAN PEMBAHASAN}

\subsection{Hasil Rekap Data Karyawan}

Data karyawan yang digunakan pada penelitian ini merupakan data presensi, masa kerja, ijin, dan disiplin karyawan pada bulan Februari 2020. Data diperoleh dari divisi HRD Merapi Online
Corporation. Data ini akan digunakan sebagai data pokok pada sistem yang akan dibangun. Data rekap karyawan ditunjukkan pada Tabel 1.

Tabel 1 Data Karyawan

\begin{tabular}{|c|c|c|c|c|c|}
\hline No & $\begin{array}{c}\text { Nama } \\
\text { Karyawan }\end{array}$ & $\mathrm{C} 1$ & $\mathrm{C} 2$ & $\mathrm{C} 3$ & $\mathrm{C} 4$ \\
\hline 1 & $\mathrm{~K} 1$ & 90 & 6 & 8 & Baik \\
\hline 2 & $\mathrm{~K} 2$ & 47 & 10 & 5 & Cukup \\
\hline 3 & $\mathrm{~K} 3$ & 69 & 10 & 8 & Kurang \\
\hline 4 & K4 & 92 & 20 & 2 & Baik \\
\hline 5 & K5 & 90 & 8 & 2 & Baik \\
\hline 6 & K6 & 37 & 10 & 11 & Cukup \\
\hline 7 & K7 & 100 & 18 & 5 & Baik \\
\hline 8 & K8 & 100 & 22 & 1 & Baik \\
\hline 9 & K9 & 67 & 5 & 6 & Cukup \\
\hline 10 & K10 & 100 & 6 & 2 & Baik \\
\hline 11 & K11 & 100 & 22 & 4 & Baik \\
\hline 12 & K12 & 90 & 2 & 7 & Baik \\
\hline 13 & K13 & 92 & 2 & 2 & Baik \\
\hline 14 & K14 & 58 & 2 & 5 & Cukup \\
\hline 15 & K15 & 90 & 2 & 8 & Baik \\
\hline 16 & K16 & 100 & 26 & 3 & Sangat Baik \\
\hline 17 & K17 & 100 & 20 & 8 & Baik \\
\hline 18 & K18 & 100 & 4 & 10 & Baik \\
\hline 19 & K19 & 100 & 26 & 9 & Baik \\
\hline 20 & K20 & 100 & 19 & 4 & Baik \\
\hline 21 & K21 & 100 & 10 & 14 & Baik \\
\hline 22 & K22 & 93 & 8 & 8 & Baik \\
\hline 23 & K23 & 90 & 8 & 8 & Baik \\
\hline 24 & K24 & 100 & 5 & 3 & Baik \\
\hline 25 & K25 & 90 & 5 & 0 & Baik \\
\hline 26 & K26 & 47 & 2 & 6 & Cukup \\
\hline 27 & K27 & 80 & 3 & 0 & Cukup \\
\hline 28 & K28 & 79 & 10 & 1 & Cukup \\
\hline 29 & K29 & 50 & 10 & 11 & Cukup \\
\hline 30 & K30 & 91 & 10 & 9 & Baik \\
\hline
\end{tabular}

Perusahaan Merapi Online Group melakukan penilaian sub kriteria pada data karyawan dengan berdasarkan nilai kriteria yang telah ditetapkan dengan pembobotan untuk masing-masing sub kriteria seperti ditunjukkan pada Tabel 2 s.d Tabel 5.

Presensi merupakan keterangan yang berisi persentase absensi karyawan selama satu bulan. Nilai presensi dihitung dengan mengalikan jumlah kehadiran dalam sebulan dikali $100 \%$. Tabel bobot presensi dapat dilihat pada Tabel 2. Tabel 2 Bobot Presensi

\begin{tabular}{cc}
\hline Presensi (\%) & Bobot \\
\hline 100 & 5 \\
$90-99$ & 4 \\
$80-89$ & 3 \\
$70-79$ & 2 \\
$<70$ & 1 \\
\hline
\end{tabular}

Masa kerja merupakan keterangan yang berisi jangka waktu atau lamanya seorang karyawan bekerja di perusahaan. Tabel bobot nilai masa kerja dapat dilihat pada Tabel 3 .

Tabel 3 Bobot Masa Kerja

\begin{tabular}{ll}
\hline Masa Kerja & Bobot \\
\hline$>5$ bulan & 5 \\
$3-4$ bulan & 4 \\
$2-3$ bulan & 3 \\
$1-2$ bulan & 2 \\
$<1$ bulan & 1 \\
\hline
\end{tabular}

Ijin merupakan keterangan yang berisi jumlah hari ijin seorang karyawan selama satu bulan. Tabel bobot ijin dapat dilihat pada Tabel 4. 


\begin{tabular}{cc}
\multicolumn{2}{c}{ Tabel 4 } \\
\hline Ijin & Bobot Ijin \\
\hline$<3$ hari & 5 \\
$3-5$ hari & 4 \\
$6-8$ hari & 3 \\
$9-11$ hari & 2 \\
$>11$ hari & 1 \\
\hline
\end{tabular}

Disiplin merupakan keterangan yang berisi jumlah pelanggaran yang dilakukan oleh karyawan selama satu bulan, pelanggaran dalam hal ini termasuk keterlambatan dan ketidak hadiran tanpa ijin serta pelanggaran lain yang ditentukan perusahaan. Tabel bobot didiplin dapat dilihat pada Tabel 5.

\begin{tabular}{cc}
\multicolumn{2}{c}{ Tabel 5 Bobot Disiplin } \\
\hline Disiplin & Bobot \\
\hline Sangat baik & 5 \\
Baik & 4 \\
Cukup & 3 \\
Kurang & 2 \\
Sangat kurang & 1 \\
\hline
\end{tabular}

Berdasar dari data karyawan dan data penilaian berdasarkan pembobotan masing-masing sub kriteria diperoleh data penilaian seperti pada Tabel 6 .

Tabel 6 Data Penilaian

\begin{tabular}{|c|c|c|c|c|}
\hline $\begin{array}{c}\text { Nama } \\
\text { Karyawan }\end{array}$ & C1 & $\mathrm{C} 2$ & C3 & $\mathrm{C} 4$ \\
\hline K01 & 4 & 4 & 3 & 4 \\
\hline K02 & 1 & 5 & 4 & 3 \\
\hline K03 & 1 & 5 & 3 & 2 \\
\hline K04 & 4 & 5 & 5 & 4 \\
\hline K05 & 4 & 5 & 5 & 4 \\
\hline K06 & 1 & 5 & 2 & 3 \\
\hline K07 & 5 & 5 & 4 & 4 \\
\hline K08 & 5 & 5 & 5 & 4 \\
\hline K09 & 1 & 4 & 3 & 3 \\
\hline K10 & 5 & 4 & 5 & 4 \\
\hline K11 & 5 & 5 & 4 & 4 \\
\hline K12 & 4 & 2 & 3 & 4 \\
\hline K13 & 4 & 2 & 5 & 4 \\
\hline K14 & 1 & 2 & 4 & 3 \\
\hline K15 & 4 & 2 & 3 & 4 \\
\hline K16 & 5 & 5 & 4 & 5 \\
\hline K17 & 5 & 5 & 3 & 4 \\
\hline K18 & 5 & 3 & 2 & 4 \\
\hline K19 & 5 & 5 & 2 & 4 \\
\hline $\mathrm{K} 20$ & 5 & 5 & 4 & 4 \\
\hline $\mathrm{K} 21$ & 5 & 5 & 1 & 4 \\
\hline $\mathrm{K} 22$ & 4 & 5 & 3 & 4 \\
\hline $\mathrm{K} 23$ & 4 & 5 & 3 & 4 \\
\hline K24 & 5 & 4 & 4 & 4 \\
\hline $\mathrm{K} 25$ & 4 & 4 & 5 & 4 \\
\hline $\mathrm{K} 26$ & 1 & 2 & 3 & 3 \\
\hline $\mathrm{K} 27$ & 3 & 3 & 5 & 3 \\
\hline $\mathrm{K} 28$ & 2 & 5 & 5 & 3 \\
\hline K29 & 1 & 5 & 2 & 3 \\
\hline $\mathrm{K} 30$ & 4 & 5 & 2 & 4 \\
\hline
\end{tabular}

\subsection{Perhitungan Metode SMART}

Pada perhitungan ini terdapat empat kriteria dan nilai utility yang sudah ditentukan, dan bisa diganti sesuai dengan kebutuhan. Jadi kriteria dan nilai disesuaikan dengan kebutuhan, berikut langkahlangkah perhitungannya:

Pertama, menentukan jumlah kriteria dan sub kriteria serta bobot kriteria. Bobot kriteria ditentukan dengan persetujuan dan kepentingan pada perusahaan
Merapi Online Corporation. Kriteria-kriteria dan sub kriteria yang digunakan dalam penentuan karyawan terbaik dilanjutkan pembobotan kriteria dilakukan dengan memberikan nilai antara $0-100$ sesuai dengan kepentingan dari masing-masing kriteria seperti dapat dilihat pada Tabel 7.

\begin{tabular}{|c|c|c|c|}
\hline No & Kriteria & Bobot (wj) & Sub Kriteria \\
\hline 1 & Presensi & 40 & $\begin{array}{l}100 \% \\
80-99 \% \\
60-79 \% \\
40-59 \% \\
<40 \%\end{array}$ \\
\hline 2 & Masa Kerja & 30 & $\begin{array}{l}>6 \text { bulan } \\
4-5 \text { bulan } \\
2-3 \text { bulan } \\
1-2 \text { bulan } \\
<2 \text { bulan }\end{array}$ \\
\hline 3 & Ijin & 20 & $\begin{array}{l}\geq 2 \text { hari } \\
3-5 \text { hari } \\
6-8 \text { hari } \\
9-11 \text { hari } \\
\geq 12 \text { hari }\end{array}$ \\
\hline 4 & Disiplin & 10 & $\begin{array}{l}\text { Sangat baik } \\
\text { Baik } \\
\text { Cukup } \\
\text { Kurang } \\
\text { Sangat kurang }\end{array}$ \\
\hline
\end{tabular}

Kedua, memberikan bobot kriteria selanjutnya adalah normalisasi bobot kriteria. Hasil normalisasi bobot kriteria dapat dilihat pada Tabel 8 .

\begin{tabular}{cll}
\multicolumn{3}{c}{ Tabel 8 Normalisasi Bobot Kriteria } \\
\hline No & Kriteria & Bobot Normalisasi (wj) \\
\hline 1 & Pendidikan & 0,40 \\
2 & Masa Kerja & 0,30 \\
3 & Ijin & 0,20 \\
4 & Disiplin & 0,10 \\
Total & & 1 \\
\hline
\end{tabular}

Ketiga, memberikan nilai utility untuk setiap masing-masing kriteria dari semua kriteria yang telah ditentukan, selanjutnya dianalisis untuk menentukan nilai pengembangan utility. Nilai yang diberikan dalam skala $0-100$. Selanjutnya hitung bobot nilai utility setiap kriteria masing-masing. Nilai utility setiap kriteria dapat dilihat pada Tabel 9.

\begin{tabular}{|c|c|c|c|c|}
\hline No & Kriteria & Sub Kriteria & Nilai & Nilai Utility \\
\hline \multirow[t]{5}{*}{1} & Presensi & $100 \%$ & 100 & 1,00 \\
\hline & & $80-99 \%$ & 75 & 0,75 \\
\hline & & $60-79 \%$ & 50 & 0,50 \\
\hline & & $40-59 \%$ & 25 & 0,25 \\
\hline & & $<40 \%$ & 0 & 0,00 \\
\hline \multirow[t]{5}{*}{2} & Masa Kerja & $>6$ bulan & 100 & 1,00 \\
\hline & & 4-5 bulan & 75 & 0,75 \\
\hline & & 2-3 bulan & 50 & 0,50 \\
\hline & & $1-2$ bulan & 25 & 0,25 \\
\hline & & $<2$ bulan & 0 & 0,00 \\
\hline \multirow[t]{5}{*}{3} & Ijin & $\geq 2$ hari & 100 & 1,00 \\
\hline & & 3-5 hari & 75 & 0,75 \\
\hline & & $6-8$ hari & 50 & 0,50 \\
\hline & & 9-11 hari & 25 & 0,25 \\
\hline & & $\geq 12$ hari & 0 & 0,00 \\
\hline \multirow[t]{5}{*}{4} & Disiplin & Sangat baik & 100 & 1,00 \\
\hline & & Baik & 75 & 0,75 \\
\hline & & Cukup & 50 & 0,50 \\
\hline & & Kurang & 25 & 0,25 \\
\hline & & Sangat kurang & 0 & 0,00 \\
\hline
\end{tabular}


Keempat, menampilkan hasil normalisasi ke dalam tabel dan menghitung nilai akhir dengan cara nilai bobot kriteria yang sudah dinormalisasi dikalikan dengan nilai utility yang sudah dinormalisasi. Hasil perhitungan nilai akhir dapat dilihat pada Tabel 10.

\begin{tabular}{|c|c|c|c|c|c|}
\hline $\begin{array}{c}\text { Nama } \\
\text { Karyawan }\end{array}$ & $\begin{array}{c}\mathrm{NU} \mathbf{x} \\
\mathrm{C1}\end{array}$ & $\begin{array}{c}\mathrm{NU} x \\
\mathrm{C} 2\end{array}$ & $\begin{array}{c}\text { NU } x \\
\text { C3 }\end{array}$ & NU x C4 & $\begin{array}{l}\text { Nilai } \\
\text { Akhir }\end{array}$ \\
\hline K01 & 0,3 & 0,225 & 0,1 & 0,075 & 0,7 \\
\hline K02 & 0,1 & 0,3 & 0,15 & 0,05 & 0,6 \\
\hline K03 & 0,2 & 0,3 & 0,1 & 0,025 & 0,625 \\
\hline K04 & 0,3 & 0,3 & 0,2 & 0,075 & 0,875 \\
\hline K05 & 0,3 & 0,3 & 0,2 & 0,075 & 0,875 \\
\hline K06 & 0 & 0,3 & 0,05 & 0,05 & 0,4 \\
\hline K07 & 0,4 & 0,3 & 0,15 & 0,075 & 0,925 \\
\hline K08 & 0,4 & 0,3 & 0,2 & 0,075 & 0,975 \\
\hline K09 & 0,2 & 0,225 & 0,1 & 0,05 & 0,575 \\
\hline K10 & 0,4 & 0,225 & 0,2 & 0,075 & 0,9 \\
\hline K11 & 0,4 & 0,3 & 0,15 & 0,075 & 0,925 \\
\hline K12 & 0,3 & 0,075 & 0,1 & 0,075 & 0,55 \\
\hline K13 & 0,3 & 0,075 & 0,2 & 0,075 & 0,65 \\
\hline K14 & 0,1 & 0,075 & 0,15 & 0,05 & 0,375 \\
\hline K15 & 0,3 & 0,075 & 0,1 & 0,075 & 0,55 \\
\hline K16 & 0,4 & 0,3 & 0,15 & 0,1 & 0,95 \\
\hline K17 & 0,4 & 0,3 & 0,1 & 0,075 & 0,875 \\
\hline K18 & 0,4 & 0,15 & 0,05 & 0,075 & 0,675 \\
\hline K19 & 0,4 & 0,3 & 0,05 & 0,075 & 0,825 \\
\hline K20 & 0,4 & 0,3 & 0,15 & 0,075 & 0,925 \\
\hline $\mathrm{K} 21$ & 0,4 & 0,3 & 0 & 0,075 & 0,775 \\
\hline K22 & 0,3 & 0,3 & 0,1 & 0,075 & 0,775 \\
\hline K23 & 0,3 & 0,3 & 0,1 & 0,075 & 0,775 \\
\hline K24 & 0,4 & 0,225 & 0,15 & 0,075 & 0,85 \\
\hline $\mathrm{K} 25$ & 0,3 & 0,225 & 0,2 & 0,075 & 0,8 \\
\hline K26 & 0,1 & 0,075 & 0,1 & 0,05 & 0,325 \\
\hline K27 & 0,3 & 0,15 & 0,2 & 0,05 & 0,7 \\
\hline K28 & 0,2 & 0,3 & 0,2 & 0,05 & 0,75 \\
\hline K29 & 0,1 & 0,3 & 0,05 & 0,05 & 0,5 \\
\hline K30 & 0,3 & 0,3 & 0,05 & 0,075 & 0,725 \\
\hline
\end{tabular}

Hasil perangkingan pada menggunakan metode SMART dapat dilihat pada Tabel 11 .

\begin{tabular}{|c|c|c|}
\hline $\begin{array}{c}\text { Nama } \\
\text { Karyawan }\end{array}$ & Nilai Akhir & Ranking \\
\hline K08 & 0,975 & 1 \\
\hline K16 & 0,95 & 2 \\
\hline K07 & 0,925 & 3 \\
\hline K11 & 0,925 & 3 \\
\hline $\mathrm{K} 20$ & 0,925 & 3 \\
\hline K10 & 0,9 & 4 \\
\hline K04 & 0,875 & 5 \\
\hline K05 & 0,875 & 5 \\
\hline K17 & 0,875 & 5 \\
\hline $\mathrm{K} 24$ & 0,85 & 6 \\
\hline K19 & 0,825 & 7 \\
\hline $\mathrm{K} 25$ & 0,8 & 8 \\
\hline K22 & 0,775 & 9 \\
\hline K23 & 0,775 & 9 \\
\hline $\mathrm{K} 21$ & 0,775 & 9 \\
\hline K28 & 0,75 & 10 \\
\hline $\mathrm{K} 30$ & 0,725 & 11 \\
\hline $\mathrm{K} 27$ & 0,7 & 12 \\
\hline K01 & 0,7 & 12 \\
\hline K18 & 0,675 & 13 \\
\hline K13 & 0,65 & 14 \\
\hline K03 & 0,625 & 15 \\
\hline K02 & 0,6 & 16 \\
\hline K09 & 0,575 & 17 \\
\hline K12 & 0,55 & 18 \\
\hline K15 & 0,55 & 18 \\
\hline K29 & 0,5 & 19 \\
\hline
\end{tabular}

\begin{tabular}{ccc}
\hline $\begin{array}{c}\text { Nama } \\
\text { Karyawan }\end{array}$ & Nilai Akhir & Ranking \\
\hline K06 & 0,4 & 20 \\
K14 & 0,375 & 21 \\
K26 & 0,325 & 22 \\
\hline
\end{tabular}

Berdasarkan perankingan nilai seluruh alternatif pada Tabel 4, diperoleh sebanyak 22 peringkat yang terdapat beberapa alternatif memiliki nilai akhir yang sama sehingga memperoleh nilai peringkat yang sama sejumlah 5 peringkat.

\subsection{Perhitungan Metode MAUT}

Langkah awal perhitungan metode MAUT adalah memasukan nilai sub kriteria yang terdiri dari 4 sub kriteria setiap alternatif. Data penilaian dapat dilihat pada Tabel 12.

\begin{tabular}{|c|c|c|c|c|}
\hline $\begin{array}{l}\text { Nama } \\
\text { Karyawan }\end{array}$ & $\mathrm{C} 1$ & $\mathrm{C} 2$ & C3 & $\mathrm{C} 4$ \\
\hline K1 & 4 & 4 & 3 & 4 \\
\hline $\mathrm{K} 2$ & 1 & 5 & 4 & 3 \\
\hline $\mathrm{K} 3$ & 1 & 5 & 3 & 2 \\
\hline K4 & 4 & 5 & 5 & 4 \\
\hline K5 & 4 & 5 & 5 & 4 \\
\hline K6 & 1 & 5 & 2 & 3 \\
\hline K7 & 5 & 5 & 4 & 4 \\
\hline K8 & 5 & 5 & 5 & 4 \\
\hline K9 & 1 & 4 & 3 & 3 \\
\hline K10 & 5 & 4 & 5 & 4 \\
\hline K11 & 5 & 5 & 4 & 4 \\
\hline K12 & 4 & 2 & 3 & 4 \\
\hline K13 & 4 & 2 & 5 & 4 \\
\hline K14 & 1 & 2 & 4 & 3 \\
\hline K15 & 4 & 2 & 3 & 4 \\
\hline K16 & 5 & 5 & 4 & 5 \\
\hline K17 & 5 & 5 & 3 & 4 \\
\hline K18 & 5 & 3 & 2 & 4 \\
\hline K19 & 5 & 5 & 2 & 4 \\
\hline K20 & 5 & 5 & 4 & 4 \\
\hline K21 & 5 & 5 & 1 & 4 \\
\hline K22 & 4 & 5 & 3 & 4 \\
\hline K23 & 4 & 5 & 3 & 4 \\
\hline $\mathrm{K} 24$ & 5 & 4 & 4 & 4 \\
\hline $\mathrm{K} 25$ & 4 & 4 & 5 & 4 \\
\hline K26 & 1 & 2 & 3 & 3 \\
\hline K27 & 3 & 3 & 5 & 3 \\
\hline K28 & 2 & 5 & 5 & 3 \\
\hline K29 & 1 & 5 & 2 & 3 \\
\hline K30 & 4 & 5 & 2 & 4 \\
\hline
\end{tabular}

Menentukan nilai tertinggi, terendah dan selisih dari nilai tertinggi dan terendah pada setiap kriteria. Hasil perhitungan nilai tertinggi, terendah dan selisih dapat dilhat pada Tabel 13.

\begin{tabular}{lcccc} 
& \multicolumn{4}{c}{ Tabel 13 Nilai Max, Min, dan Selisih } \\
\hline Nilai & C1 & C2 & C3 & C4 \\
\hline Maksimal & 5 & 5 & 5 & 5 \\
Minimal & 1 & 2 & 1 & 2 \\
Selisih & 4 & 3 & 4 & 3 \\
\hline
\end{tabular}

Perhitungan normalisasi kriteria pertama dari nilai tertinggi dan terendah (Utilitas) dapat dilihat pada Tabel 14.

Selanjutnya menghitung hasil perhitungan normalisasi kriteria dikalikan dengan bobot. Bobot preferensi dari setiap kriteria dapat dilihat pada Tabel 15. 
Tabel 14 Normalisasi Utilitas

\begin{tabular}{|c|c|c|c|c|}
\hline $\begin{array}{l}\text { Nama } \\
\text { Karyawan }\end{array}$ & $\mathrm{C} 1$ & $\mathrm{C} 2$ & C3 & C3 \\
\hline K1 & 0,7500 & 0,6667 & 0,5000 & 0,6667 \\
\hline $\mathrm{K} 2$ & 0,0000 & 1,0000 & 0,7500 & 0,3333 \\
\hline $\mathrm{K} 3$ & 0,0000 & 1,0000 & 0,5000 & 0,0000 \\
\hline K4 & 0,7500 & 1,0000 & 1,0000 & 0,6667 \\
\hline K5 & 0,7500 & 1,0000 & 1,0000 & 0,6667 \\
\hline K6 & 0,0000 & 1,0000 & 0,2500 & 0,3333 \\
\hline K7 & 1,0000 & 1,0000 & 0,7500 & 0,6667 \\
\hline K8 & 1,0000 & 1,0000 & 1,0000 & 0,6667 \\
\hline K9 & 0,0000 & 0,6667 & 0,5000 & 0,3333 \\
\hline K10 & 1,0000 & 0,6667 & 1,0000 & 0,6667 \\
\hline K11 & 1,0000 & 1,0000 & 0,7500 & 0,6667 \\
\hline K12 & 0,7500 & 0,0000 & 0,5000 & 0,6667 \\
\hline K13 & 0,7500 & 0,0000 & 1,0000 & 0,6667 \\
\hline K14 & 0,0000 & 0,0000 & 0,7500 & 0,3333 \\
\hline K15 & 0,7500 & 0,0000 & 0,5000 & 0,6667 \\
\hline K16 & 1,0000 & 1,0000 & 0,7500 & 1,0000 \\
\hline K17 & 1,0000 & 1,0000 & 0,5000 & 0,6667 \\
\hline K18 & 1,0000 & 0,3333 & 0,2500 & 0,6667 \\
\hline K19 & 1,0000 & 1,0000 & 0,2500 & 0,6667 \\
\hline K20 & 1,0000 & 1,0000 & 0,7500 & 0,6667 \\
\hline K21 & 1,0000 & 1,0000 & 0,0000 & 0,6667 \\
\hline K22 & 0,7500 & 1,0000 & 0,5000 & 0,6667 \\
\hline K23 & 0,7500 & 1,0000 & 0,5000 & 0,6667 \\
\hline K24 & 1,0000 & 0,6667 & 0,7500 & 0,6667 \\
\hline $\mathrm{K} 25$ & 0,7500 & 0,6667 & 1,0000 & 0,6667 \\
\hline K26 & 0,0000 & 0,0000 & 0,5000 & 0,3333 \\
\hline K27 & 0,5000 & 0,3333 & 1,0000 & 0,3333 \\
\hline K28 & 0,2500 & 1,0000 & 1,0000 & 0,3333 \\
\hline K29 & 0,0000 & 1,0000 & 0,2500 & 0,3333 \\
\hline K30 & 0,7500 & 1,0000 & 0,2500 & 0,6667 \\
\hline
\end{tabular}

Tabel 15 Normalisasi Bobot Kriteria

\begin{tabular}{lll}
\hline Nama Kriteria & Kode & Bobot \\
\hline Presensi & C1 & 0,4 \\
Masa Kerja & C2 & 0,3 \\
Ijin & C 3 & 0,2 \\
Disiplin & C4 & 0,1 \\
\hline
\end{tabular}

Hasil perhitungan normalisasi dikali nilai bobot dapat dilihat pada Tabel 16.

Tabel 16 Hasil Normalisasi x Bobot

\begin{tabular}{|c|c|c|c|c|}
\hline $\begin{array}{l}\text { Nama } \\
\text { Karyawan }\end{array}$ & C1 & $\mathrm{C2}$ & $\mathrm{C2}$ & C4 \\
\hline K1 & 0,3 & 0,2 & 0,1 & 0,066666667 \\
\hline $\mathrm{K} 2$ & 0 & 0,3 & 0,15 & 0,033333333 \\
\hline $\mathrm{K} 3$ & 0 & 0,3 & 0,1 & 0 \\
\hline K4 & 0,3 & 0,3 & 0,2 & 0,066666667 \\
\hline K5 & 0,3 & 0,3 & 0,2 & 0,066666667 \\
\hline K6 & 0 & 0,3 & 0,05 & 0,033333333 \\
\hline K7 & 0,4 & 0,3 & 0,15 & 0,066666667 \\
\hline K8 & 0,4 & 0,3 & 0,2 & 0,066666667 \\
\hline K9 & 0 & 0,2 & 0,1 & 0,033333333 \\
\hline K10 & 0,4 & 0,2 & 0,2 & 0,066666667 \\
\hline K11 & 0,4 & 0,3 & 0,15 & 0,066666667 \\
\hline $\mathrm{K} 12$ & 0,3 & 0 & 0,1 & 0,066666667 \\
\hline K13 & 0,3 & 0 & 0,2 & 0,0666666667 \\
\hline K14 & 0 & 0 & 0,15 & 0,033333333 \\
\hline K15 & 0,3 & 0 & 0,1 & 0,066666667 \\
\hline K16 & 0,4 & 0,3 & 0,15 & 0,1 \\
\hline K17 & 0,4 & 0,3 & 0,1 & 0,066666667 \\
\hline K18 & 0,4 & 0,1 & 0,05 & 0,0666666667 \\
\hline K19 & 0,4 & 0,3 & 0,05 & 0,066666667 \\
\hline $\mathrm{K} 20$ & 0,4 & 0,3 & 0,15 & 0,0666666667 \\
\hline $\mathrm{K} 21$ & 0,4 & 0,3 & 0 & 0,066666667 \\
\hline $\mathrm{K} 22$ & 0,3 & 0,3 & 0,1 & 0,0666666667 \\
\hline $\mathrm{K} 23$ & 0,3 & 0,3 & 0,1 & 0,066666667 \\
\hline $\mathrm{K} 24$ & 0,4 & 0,2 & 0,15 & 0,0666666667 \\
\hline K25 & 0,3 & 0,2 & 0,2 & 0,066666667 \\
\hline K26 & 0 & 0 & 0,1 & 0,033333333 \\
\hline $\mathrm{K} 27$ & 0,2 & 0,1 & 0,2 & 0,033333333 \\
\hline $\mathrm{K} 28$ & 0,1 & 0,3 & 0,2 & 0,033333333 \\
\hline
\end{tabular}

\begin{tabular}{lrrrl}
\hline $\begin{array}{l}\text { Nama } \\
\text { Karyawan }\end{array}$ & C1 & \multicolumn{1}{c}{ C2 } & C2 & C4 \\
\hline K29 & 0 & 0,3 & 0,05 & 0,033333333 \\
K30 & 0,3 & 0,3 & 0,05 & 0,066666667 \\
\hline
\end{tabular}

Tahap akhir menentukan jumlah seluruh nilai pada masing-masing alternatif yang selanjutnya akan diranking berdasarkan urutan nilai paling besar sampai dengan nilai paling kecil. Hasil akhir dapat dilihat pada Tabel 17.

\begin{tabular}{lr}
\multicolumn{2}{c}{ Tabel 17 Hasil Akhir } \\
\hline Nama \\
Karyawan & \multicolumn{1}{l}{ Hasil Akhir } \\
\hline K1 & 0,666666667 \\
K2 & 0,483333333 \\
K3 & 0,4 \\
K4 & 0,866666667 \\
K5 & 0,866666667 \\
K6 & 0,383333333 \\
K7 & 0,916666667 \\
K8 & 0,966666667 \\
K9 & 0,333333333 \\
K10 & 0,866666667 \\
K11 & 0,916666667 \\
K12 & 0,466666667 \\
K13 & 0,566666667 \\
K14 & 0,183333333 \\
K15 & 0,466666667 \\
K16 & 0,95 \\
K17 & 0,866666667 \\
K18 & 0,616666667 \\
K19 & 0,816666667 \\
K20 & 0,916666667 \\
K21 & 0,766666667 \\
K22 & 0,766666667 \\
K23 & 0,766666667 \\
K24 & 0,816666667 \\
K25 & 0,766666667 \\
K26 & 0,133333333 \\
K27 & 0,533333333 \\
K28 & 0,633333333 \\
K29 & 0,383333333 \\
K30 & 0,716666667 \\
\hline & \\
& \\
\hline
\end{tabular}

Perankingan dari hasil akhir dapat dilihat pada Tabel 18.

\begin{tabular}{lrc}
\multicolumn{2}{c}{ Tabel 18 Perankingan Metode MAUT } \\
\hline Nama & Hasil Akhir & Ranking \\
Karyawan & & 1 \\
K8 & 0,966666667 & 2 \\
K16 & 0,95 & 3 \\
K7 & 0,916666667 & 3 \\
K11 & 0,916666667 & 3 \\
K20 & 0,916666667 & 4 \\
K4 & 0,866666667 & 4 \\
K5 & 0,866666667 & 4 \\
K10 & 0,866666667 & 4 \\
K17 & 0,866666667 & 5 \\
K19 & 0,816666667 & 5 \\
K24 & 0,816666667 & 6 \\
K22 & 0,766666667 & 6 \\
K23 & 0,766666667 & 6 \\
K21 & 0,766666667 & 6 \\
K25 & 0,766666667 & 6 \\
K30 & 0,716666667 & 7 \\
K1 & 0,666666667 & 8 \\
K28 & 0,633333333 & 9 \\
K18 & 0,616666667 & 10 \\
K13 & 0,566666667 & 11 \\
K27 & 0,533333333 & 13 \\
K2 & 0,483333333 & \\
K12 & 0,466666667 & 13 \\
K15 & 0,466666667 & \\
\hline & & \\
\hline & & 11 \\
\hline
\end{tabular}




\begin{tabular}{lrc}
\hline $\begin{array}{l}\text { Nama } \\
\text { Karyawan }\end{array}$ & Hasil Akhir & Ranking \\
\hline K3 & 0,4 & 14 \\
K6 & 0,383333333 & 15 \\
K29 & 0,383333333 & 15 \\
K9 & 0,333333333 & 16 \\
K14 & 0,183333333 & 17 \\
K26 & 0,133333333 & 18 \\
\hline
\end{tabular}

Berdasarkan perankingan nilai preferensi seluruh alternatif pada Tabel 18, terdapat beberapa alternatif memiliki nilai preferensi yang sama sehingga memperoleh nilai peringkat yang sama. Hasil perangkingan menunjukkan terdapat 18 ranking pada hasil perhitungan MAUT dengan 6 ranking sama.

3.4 Perbandingan ranking metode SMART dan MAUT

Hasil perbandingan kedua metode dapat dilihat pada Tabel 18. Dapat diketahui bahwa terdapat perbedaan antara kedua metode. Pada metode SMART menghasilkan 22 ranking sedangkan pada metode MAUT menghasilkan 18 ranking.

Tabel 19 Hasil Perbandingan Metode SMART dan MAUT

\begin{tabular}{crrccc}
\hline \multicolumn{2}{c}{ Metode SMART } & \multicolumn{4}{c}{ Metode MAUT } \\
Karyawan & \multicolumn{1}{c}{ Hasil } & \multicolumn{1}{c}{ Rank } & Karyawan & V & Rank \\
\hline K08 & 0,975 & 1 & K08 & 0,966666667 & 1 \\
K16 & 0,95 & 2 & K16 & 0,95 & 2 \\
K07 & 0,925 & 3 & K07 & 0,916666667 & 3 \\
K11 & 0,925 & 3 & K11 & 0,916666667 & 3 \\
K20 & 0,925 & 3 & K20 & 0,916666667 & 3 \\
K10 & 0,9 & 4 & K10 & 0,866666667 & 4 \\
K04 & 0,875 & 5 & K24 & 0,866666667 & 4 \\
K05 & 0,875 & 5 & K17 & 0,866666667 & 4 \\
K17 & 0,875 & 5 & K04 & 0,866666667 & 4 \\
K24 & 0,85 & 6 & K05 & 0,816666667 & 5 \\
K19 & 0,825 & 7 & K25 & 0,816666667 & 5 \\
K25 & 0,8 & 8 & K19 & 0,766666667 & 6 \\
K22 & 0,775 & 9 & K22 & 0,766666667 & 6 \\
K23 & 0,775 & 9 & K23 & 0,766666667 & 6 \\
K21 & 0,775 & 9 & K01 & 0,766666667 & 6 \\
K28 & 0,75 & 10 & K21 & 0,716666667 & 6 \\
K30 & 0,725 & 11 & K18 & 0,666666667 & 7 \\
K27 & 0,7 & 12 & K30 & 0,633333333 & 8 \\
K01 & 0,7 & 12 & K13 & 0,616666667 & 9 \\
K18 & 0,675 & 13 & K12 & 0,566666667 & 10 \\
K13 & 0,65 & 14 & K15 & 0,533333333 & 11 \\
K03 & 0,625 & 15 & K27 & 0,483333333 & 12 \\
K02 & 0,6 & 16 & K28 & 0,466666667 & 13 \\
K09 & 0,575 & 17 & K02 & 0,466666667 & 13 \\
K12 & 0,55 & 18 & K03 & 0,4 & 14 \\
K15 & 0,55 & 18 & K06 & 0,383333333 & 15 \\
K29 & 0,5 & 19 & K29 & 0,383333333 & 15 \\
K06 & 0,4 & 20 & K09 & 0,333333333 & 16 \\
K14 & 0,375 & 21 & K14 & 0,183333333 & 17 \\
K26 & 0,325 & 22 & K26 & 0,133333333 & 18 \\
\hline & & & & &
\end{tabular}

\section{KESIMPULAN}

Hasil perhitungan menggunakan metode SMART dan MAUT menunjukkan bahwa metode dapat berfungsi dengan baik, algoritma SMART dan MAUT berhasil diimplementasikan untuk menghitung perangkingan karyawan, sehingga dapat disimpulkan bahwa kedua metode memiliki performa yang baik untuk menentukan karyawan terbaik. Pada hasil perankingan SMART dan MAUT, terlihat bahwa algoritma SMART mampu memberikan hasil yang lebih baik daripada MAUT. Hal ini terlihat dari jumlah peringkat alternatif yang muncul. Pada perhitungan ini menggunakan data alternatif, bobot kriteria, serta nilai alternatif yang sama. Dari hasil perhitungan SMART yakni sejumlah 22 peringkat, berbeda dengan MAUT yang hanya mampu menampilkan 18 peringkat. Semakin banyak jumlah peringkat yang muncul dari hasil perhitungan semakin baik, karena algoritma tersebut terbukti mampu meminimalisir nilai preferensi yang sama, sehingga perankingan alternatif dapat dilakukan dengan baik.

Adapun saran yang dapat diberikan penulis untuk penelitian selanjutnya yaitu penelitian selanjutnya diharapkan dapat dilakukan dengan membuat analisis perbandingan dengan menggunakan metode lain selain SMART dan MAUT. Sistem pendukung keputusan dapat dilakukan penggabungan dengan metode lain seperti Analytical Hierarchy Process (AHP) maupun Analytic Network Process (ANP) dalam mengatasi masalah pembobotan kriteria. Diharapkan dengan adanya hasil analisis mengenai perbandingan kedua metode, pada penelitian selanjutnya menemukan metode baru yang lebih baik yang berdasarkan dari gabungan dua metode.

\section{DAFTAR PUSTAKA}

FAJARWATI, I., FITRIASARI, N.S. AND SIREGAR, H., 2018. Perbandingan Metode Weighted Product (WP), Weighted Sum Model (WSM) Dan Multi Attribute Utility Theory (MAUT) Dalam Sistem Pendukung Keputusan Penerimaan Tenaga Kerja. Jurnal Teori dan Aplikasi Ilmu Komputer, 1(1), pp.25-32.

FITRIANI, D., 2019. Sistem Pendukung Keputusan Penentuan Karyawan Terbaik Pada Collection Pt. Panin Bank Menggunakan. Jurnal Mantik Penusa, [online] 3(1), pp.18. Available at: <http://ejurnal.pelitanusantara.ac.id/index.php/manti $\mathrm{k} /$ article/view/521>.

HADINATA, N., 2018. Implementasi Metode Multi Attribute Utility Theory (MAUT) Pada Sistem Pendukung Keputusan dalam Menentukan Penerima Kredit. Jurnal Sisfokom (Sistem Informasi dan Komputer), 7(2), p.87.

HIDAYAT, M., JUSIA, P.A. AND AMRONI, 2018. Analisa dan Perancangan Sistem Pendukung Keputusan Untuk Penerimaan Karyawan PT . Dos Ni Roha Jambi Menggunakan Metode MAUT ( Multi Attribute Utility Theory ). Processor, 13(1).

ISRAWAN, L.M.F., MUKMIN, M. AND ARDIANSYAH, S., 2018. Penentuan Karyawan Berprestasi Menggunakan Metode Multi Attribute Utility Theory ( Maut ). Jurnal Informatika, 9(1).

LESTARI, A.B. AND MAHDIANA, D., 2019. Penerapan Metode Analitycal Hierarchy 
Process Dan Simple Multi Attribute Rating Technique Untuk Pemilihan Supplier. Proceeding SINTAK 2019, pp.306-313.

MANALU, A.S., 2018. Sistem Pendukung Keputusan Karyawan Teladan Dengan metode SMART (Simple Multi Attribute Rating Technique) Berbasis Web (Studi Kasus: PT.Devin Buana Perkasa). Sekolah Tinggi Manajemen Informatika dan Komputer (STMIK) Gici Batam.

NASYUHA, A.H., 2019. Sistem Pendukung Keputusan Menentukan Pemberian Pinjaman Modal dengan Metode Multi Attribute Utility Theory. Jurnal Media Informatika Budidarma, 3(2), p.117.

PRIATNA, H., MULYANA, J. AND DEDIH, 2016. Perbandingan metode SMART dan Simple Additive Weighting (SAW) dalam Menentukan Karyawan Tetap Berbasis Web. UNSIKA Syntax Jurnal Informatika, 5(1), pp.53-85.

RAFIQI, A., RIYANSYAH, D. AND SARTIKA, H., 2018. Sistem Pendukung Keputusan Penentuan Karyawan Terbaik Menggunakan Metode MOORA. Seminar Nasional Sains \& Teknologi Informasi, 2(1), pp.73-82.

RAMADIANI, R.; AND RAHMAH, A., 2019. Sistem Pendukung keputusan pemilihan tenaga kesehatan teladan menggunakan metode Multi-Attribute Utility Theory. Jurnal Ilmiah teknologi sistem informasi, 3(2), pp.83-88.

SETIAWAN, W., PRANOTO, N. AND HUDA, K., 2020. Sistem Pendukung Keputusan Evaluasi Kinerja Karyawan dengan Metode SMART (Simple Multi Attribute Rating Technique). Jurnal Resti, 4, pp.50-55.

SIRINGORINGO, F. AND PURBA, N.O.D., 2019. Sistem Pendukung Keputusan Penilaian Kinerja Dosen dengan Metode MAUT (Multi Attribute Utility Theory). Jurnal SENSASI, 3(2), p.117.

VERADILLA AMALIA, YANTO, R. AND HAMIDANI, S., 2020. Komparasi Metode Saw Dan Smart Penerima Kartu Indonesia Pintar (KIP). 12(01), pp.90-98.

WADLY, F. AND PRIHANDOKO, 2019. Perbandingan Metode AHP dan SMART Pada Performance Appraisal Dosen untuk Pemberian Insentif Kinerja. Jurnal Teknik dan Informatika, 6(1), pp.1-5. 
Halaman ini sengaja dikosongkan 